Article

\title{
Evaluation of the Light/Dark Cycle and Concentration of Tannery Wastewater in the Production of Biomass and Metabolites of Industrial Interest from Microalgae and Cyanobacteria
}

\author{
Néstor A. Urbina-Suarez ${ }^{1,2} \mathbb{D}$, Darly D. Ayala-González ${ }^{1}$, Jennyfer D. Rivera-Amaya ${ }^{1}$, \\ Andrés F. Barajas-Solano ${ }^{1}$ (D) and Fiderman Machuca-Martínez $2,3, *$ (D) \\ 1 Department of Environmental Sciences, Universidad Francisco de Paula Santander, \\ Av. Gran Colombia No. 12E-96, Cucuta 540003, Colombia; nestorandresus@ufps.edu.co (N.A.U.-S.); \\ darlyngdayanaag@ufps.edu.co (D.D.A.-G.); jennyferdayanara@ufps.edu.co (J.D.R.-A.); \\ andresfernandobs@ufps.edu.co (A.F.B.-S.) \\ 2 School of Natural Resources and Environment, Universidad del Valle, Cali 760015, Colombia \\ 3 Escuela de Ingeniería Química, Universidad del Valle, Cali 760015, Colombia \\ * Correspondence: fiderman.machuca@correounivalle.edu.co
}

check for updates

Citation: Urbina-Suarez, N.A.; Ayala-González, D.D.;

Rivera-Amaya, J.D.;

Barajas-Solano, A.F.;

Machuca-Martínez, F. Evaluation of the Light/Dark Cycle and Concentration of Tannery Wastewater in the Production of Biomass and Metabolites of Industrial Interest from Microalgae and Cyanobacteria. Water 2022, 14, 346. https:// doi.org/10.3390/w14030346

Academic Editor: Jibiao Zhang

Received: 7 December 2021

Accepted: 10 January 2022

Published: 25 January 2022

Publisher's Note: MDPI stays neutral with regard to jurisdictional claims in published maps and institutional affiliations.

Copyright: (c) 2022 by the authors. Licensee MDPI, Basel, Switzerland. This article is an open access article distributed under the terms and conditions of the Creative Commons Attribution (CC BY) license (https:// creativecommons.org/licenses/by/ $4.0 /)$.

\begin{abstract}
The tanning industry transforms animal skins into leather and produces liquid effluents with a high organic and inorganic pollutant load. This work evaluated the effect of the tannery wastewater (TWW) concentration and the light/dark cycle on the production of biomass, carbohydrates, proteins, lipids, and pigments (carotenoids and phycobiliproteins) on two microalgae (Chlorella sp. and Scenedesmus sp.) and one cyanobacterium (Hapalosiphon sp.). A non-factorial central experimental design with a response surface was implemented using the STATISTICA 7.0 software. High removal percentages for nitrates (97\%), phosphates (73.3\%), and chemical oxygen demand $(93.2 \%)$ were achieved with the three strains. The results also highlight that the use of a constant light regime (24:0) and the concentration of real TWW affect the biomass production, since the highest concentration of biomass recorded was $1.31 \mathrm{~g} \mathrm{~L}^{-1}$ of Hapalosiphon sp. with $100 \%$ undiluted wastewater.
\end{abstract}

Keywords: microalgae; tannery effluents; carbohydrates; lipids; proteins

\section{Introduction}

The leather manufacturing process is a widely developed activity. Asia and Latin America are the highest producers globally, producing 5067 and 2359.12 tons per year, respectively, followed by Europe with 2359, Africa with 1616, North America with 1230 tons, and Oceania with 585 tons per year. To process these, an average of $10-25 \mathrm{~m}^{3}$ of clean water is used in the different stages of the tannery process. This process generates a considerable volume of untreated wastewater, which is finally discharged into other bodies of water [1]. These effluents contain a high concentration of contaminating organic matter due to the presence of particles of blood, meat, hair, soluble proteins, and fertilizer. Additionally, different salts are used in the transformation process mainly sulfur and chromium, which are used as tanning agents thus generating a high concentration of heavy metal pollutants such as $\mathrm{Fe} \mathrm{Cd}, \mathrm{Cr}, \mathrm{Pb}, \mathrm{Zn}$, and $\mathrm{Cu}$, these metals are not biodegradable and their discharge in lakes and rivers can produce bioaccumulation in living organisms [2]. At present, the physicochemical methods employed in this process are expensive and generate secondary pollutants. Coagulation has been widely used due to its ease of operation; however, this process may generate secondary wastes. Likewise, compounds such as aluminum sulfate and ferric chloride affect the removal of suspended solids, COD, and chromium up to $46 \%, 37 \%$, and $99 \%$, respectively, at optimum coagulant concentrations and optimum 
$\mathrm{pH}$ values (7.5) [3,4]. Other processes, such as electrocoagulation, can remove up to $82 \%$ of COD $[5,6]$. These technologies improve the quality of tannery wastewater and allow the removal of pollutant compounds; However, these treatment systems have disadvantages due to their high production of toxic sludge, high operating cost, complicated management and limited use in developing countries $[7,8]$.

Microalgae and cyanobacterium are renowned for their high photosynthetic efficiency and ability to generate different metabolites of interest, such as lipids [9], proteins [10], pigments [11], and carbohydrates [12]. Three key elements are needed to produce this microorganism: (1) a carbon source (usually in the form of $\mathrm{CO}_{2}$ or inorganic form); (2) a culture medium with a sufficient nutrient concentration; and (3) a source of energy-in this case, light, which is known as photosynthetically active radiation [13,14]. According to various Life Cycle Analyses (LCAs) of microalgal production, the energy required to obtain the nutrients necessary to produce microalgae biomass is very high $[15,16]$. Therefore, knowing the technical and economic feasibility of the use of different types of wastewater (domestic and industrial) as alternative sources of $\mathrm{N}$ and $\mathrm{P}$ (especially $\mathrm{NO}_{3}{ }^{-}$and $\mathrm{PO}_{4}{ }^{-3}$ ) is crucial in order to increase the sustainability of the process and improve the added value of the algal biomass $[17,18]$. Several species belonging to the genera Chlorella, Scenedesmus, Arkistrodesmus, Arthrospira, and Hapalosiphon sp. have been tested for their ability to grow in different types of wastewater $[1,19,20]$. In these systems, algae transform hazardous nutrients into biomass which can be later used to extract other metabolites, making it an interesting biotechnological tool for use in wastewater treatment [21,22] Another essential characteristic of these microorganisms is their capacity to bioaccumulate heavy metals, which may increase their potential as a sustainable alternative for the treatment of tannery wastewater [23-25].

It has been demonstrated that some strains of Chlorella and Scenedesmus sp. possess tolerance to heavy metals and other pollutants present in tannery effluents due to the activation of antioxidant enzymes (superoxide dismutase, catalase, and ascorbate peroxidase) that protect them from oxidative damage induced by the presence of metals [26]. However, to the best of the author's knowledge there are no references regarding the treatment of raw tannery effluent as a culture medium by algae or cyanobacterium. This could be due to the presence of high concentrations of toxic pollutants and the dark color of the raw effluent, which prevents light from entering the medium; the latter limits the growth of microalgae and suggests the application of dilutions of wastewater to allow better adaptation $[27,28]$ and the determination of the appropriate photoperiod [29] to allow the adequate growth of the microalgal biomass and in order to obtain metabolites of interest.

To the best of the author's knowledge, the literature on the utilization of tannery wastewater using microalgae is scarce. The use of microalgae consortia using tannery wastewater effluents after primary treatment has been reported [30]; similarly, the effect of light on the removal efficiency of Scenedesmus sp. has been reported for this type of wastewater [25]. To date, there have been no reports on the application of Hapalosiphon sp. in tannery wastewater; likewise, there have been no reports of the use of tannery wastewater for obtaining metabolites of interest from microalgae and Hapalosiphon sp. Therefore. this work is one of the first in this area. Currently, there is a gap in the literature regarding the influence of photoperiod and the concentration of tannery wastewater on biomass production and obtaining metabolites of interest (lipids, proteins, carbohydrates, phycocyanins, carotenoids, and phytohormones) from Chlorella sp., Scenedesmus sp., and Hapalosiphon $\mathrm{sp}$. Therefore, this research evaluated the effect of the tannery wastewater (TA) concentration and the light/dark ratio on biomass production to find the optimal conditions for the extraction of lipids, carbohydrates, EPSs, carotenoids, proteins, and phycobiliproteins (PE, C-PC, and A-PC). We also evaluated the nutrient assimilation capacity of nitrogen and phosphorus and achieved a reduction in the pollutant load in terms of COD, BOD, and TOC. 


\section{Materials and Methods}

\subsection{Tannery Wastewater}

The tannery wastewater was obtained from a business located in the city of Cúcuta (Norte de Santander, Colombia). The wastewater was evaluated regarding for its concentration of nitrates $\left(\mathrm{NO}_{3}\right)$, nitrites $\left(\mathrm{NO}_{2}\right)$, ammonia nitrogen $\left(\mathrm{N}-\mathrm{NH}_{3}\right)$, phosphates $\left(\mathrm{PO}_{4}\right)$, chemical oxygen demand (COD), biochemical oxygen demand (BOD), fats and oils, color, and $\mathrm{pH}$ using standard methodology [31,32]. Heavy metals ( $\mathrm{Cr}, \mathrm{Ni}, \mathrm{Cd}, \mathrm{Cu}, \mathrm{Co}$, and Zn) were measured by atomic absorption spectrophotometry (ICE 3500, Thermo Scientific, Waltham, MA, USA) [31].

\subsection{Microorganisms}

Three strains from the INNOValgae collection (UFPS, Cúcuta, Colombia) were used. Two microalgae (Chlorella sp. and Scenedesmus sp.) and a cyanobacterium (Hapalosiphon sp.) were used. The inoculums were kept in Bold Basal medium for microalgae and in BG-11 medium for cyanobacterium. The culture conditions were: 12:12 photoperiod with a constant radiation of $110 \mu \mathrm{mol} \mathrm{m}^{-2} \mathrm{~s}^{-1}, 0.6 \mathrm{vvm}$ air mixing, and $25 \pm 2{ }^{\circ} \mathrm{C}$.

\subsection{Experimental Design}

Tannery wastewater contains recalcitrant compounds that can inhibit the growth and production of metabolites of interest; likewise, the assimilation of carbon, nitrogen, and phosphorus compounds can be affected by the concentration in the effluent. To determine the effect of the concentration of tannery wastewater (TA) and the effect of the light/dark cycle, a central non-factorial experimental design was used with the STATISTICA 7.0 software, as shown in Table 1. Biomass was the main response variable, since the higher the biomass concentration was, the greater the capacity to assimilate the pollutants present in tannery wastewater was. Other response variables used were COD, TOC, nitrates, and phosphates.

Table 1. Experimental design for biomass production.

\begin{tabular}{cccc}
\hline Experiment & Block & \% TWW & Light/Dark Cycle \\
\hline 1 & 1 & 20 & 8 \\
2 & 1 & 20 & 18 \\
3 & 1 & 50 & 8 \\
4 & 1 & 50 & 18 \\
$5(\mathrm{C})$ & 1 & 35 & 13 \\
6 & 2 & 13.8 & 13 \\
7 & 2 & 56.2 & 13 \\
8 & 2 & 35 & 5.92 \\
9 & 2 & 35 & 20.07 \\
$10(\mathrm{C})$ & 2 & 35 & 13 \\
\hline
\end{tabular}

\subsection{Biomass Production and Nutrient Removal}

Prior to the inoculation of the strains, the tannery wastewater was autoclaved and its $\mathrm{pH}$ adjusted to 7.0. The different strains were cultured in $500 \mathrm{~mL}$ sterile glass flasks with a working volume of $250 \mathrm{~mL}$ of sample $\left(30 \mathrm{~mL}\right.$ of algal inoculum-equivalent to $0.1 \mathrm{~g} \mathrm{~L}^{-1}$ for Chlorella sp., $0.09 \mathrm{~g} \mathrm{~L}^{-1}$ Scenedesmus sp., and $0.103 \mathrm{~g} \mathrm{~L}^{-1}$ for Hapasplosiphon sp.). The flasks were kept in constant aeration with a flow of $0.6 \mathrm{vvm}$. The wastewater concentrations and the light/dark cycles were adjusted according to the experimental design.

To determine the biomass concentration (ash free), $5 \mathrm{~mL}$ was taken, filtered on GFC glass fiber filters and dried in an oven at $60^{\circ} \mathrm{C}$ for $24 \mathrm{~h}$ on a silica gel bed. After drying, the filters were kept in the desiccator until they reached a constant weight $( \pm 2 \mathrm{~h})$, then weighed [33]. Measurements of nitrates, phosphates, and COD were completed via the standard methodology [31]. For $\mathrm{PO}_{4}$, the vanadomolybdophosphoric acid colorimetric method was used (SM-4500-P C). For nitrates, the ultraviolet spectrophotometric detection 
method was used (SM-4500-NO $\left.\mathrm{NO}_{3}-\mathrm{B}\right)$. For $\mathrm{COD}$, the closed reflux colorimetric method was used (SM-5220 D). The samples analyzed were taken in triplicate.

Total organic carbon (TOC) was determined using a TOC analyzer (Thermo Fisher Scientific). The operating conditions were a sample volume of $0.5 \mathrm{~mL}$, water chase volume $1.0 \mathrm{~mL}$, injection line rinse on, injection line rinse volume $0.5 \mathrm{~mL}$, acid volume $0.5 \mathrm{~mL}$, ICS parge flow $200 \mathrm{~mL} \mathrm{~min}^{-1}$, carrier gas delay time $0.40 \mathrm{~min}$, ICS parge time $50 \mathrm{~min}$, detector sweep flow $500 \mathrm{~mL} \mathrm{~min}^{-1}$, furnace sweep time $1.0 \mathrm{~min}$, and system flow $200 \mathrm{~mL} \mathrm{~min}{ }^{-1}$.

\subsection{Protein Extraction and Quantification}

A filter with a known amount of biomass was submerged in a Falcon tube with $3 \mathrm{~mL}$ of $24 \%$ trichloroacetic acid (TCA) [34]. The sample was heated in a water bath at $95^{\circ} \mathrm{C}$ for $15 \mathrm{~min}$. A total of $9 \mathrm{~mL}$ of ultra-pure water was added and then centrifuged at $15,000 \times \mathrm{rpm}$ for $20 \mathrm{~min}$ at $4{ }^{\circ} \mathrm{C}$. The pellet was resuspended in $0.5 \mathrm{~mL}$ of Lowry $\mathrm{D}$ reagent and brought to $55^{\circ} \mathrm{C}$ for $60 \mathrm{~min}$ in a water bath. Each tube was centrifuged twice at $4500 \mathrm{rpm}$ for $15 \mathrm{~min}$. A total of $175 \mu \mathrm{L}$ of the supernatant was taken and $3325 \mu \mathrm{L}$ of Lowry D was added. It was incubated $10 \mathrm{~min}$ at room temperature, $350 \mu \mathrm{L}$ of Folin-Ciocalteu reagent was added, and finally it was left to rest for $30 \mathrm{~min}$ at room temperature before the absorbance at a wavelength of $600 \mathrm{~nm}$ was read [33]. To determine the concentration, a calibration curve was established in the range of 0 to $5000 \mathrm{ug} \mathrm{L}^{-1}$; protein quantification was carried out according to Equation (1):

$$
\text { Total protein }\left(\mathrm{mg} \mathrm{L}^{-1}\right)=(2038.5 * \text { OD } 600)+59.706
$$

\subsection{Carbohydrate Extraction and Quantification}

A filter with a known amount of biomass was placed in a Falcon tube with $0.5 \mathrm{~mL}$ of $1 \mathrm{M} \mathrm{H}_{2} \mathrm{SO}_{4}$. This was homogenized in a vortex for $2 \mathrm{~min}$, then $5 \mathrm{~mL}$ of $1 \mathrm{M} \mathrm{H}_{2} \mathrm{SO}_{4}$ was added and it was incubated in a water bath at $100^{\circ} \mathrm{C}$ for $1 \mathrm{~h}$. The sample was centrifuged at $4000 \mathrm{rpm}$ at $5{ }^{\circ} \mathrm{C}$ for $10 \mathrm{~min}$. A total of $2 \mathrm{~mL}$ of the supernatant was taken in a glass tube and $1 \mathrm{~mL}$ of $5 \%$ phenol was added. The mixture was stirred vigorously and $5 \mathrm{~mL}$ of concentrated $\mathrm{H}_{2} \mathrm{SO}_{4}$ solution was quickly added. The sample was shaken using vortex at medium speed for $1 \mathrm{~min}$ and allowed to rest at room temperature for $30 \mathrm{~min}$ before it was finally read at $485 \mathrm{~nm}$ [33]. To determine the concentration, a calibration curve was established in the range of 0 to $1.5 \mathrm{mg} \mathrm{L}^{-1}$; the total carbohydrates were calculated using Equation (2):

$$
\text { Total carbohydrates }\left(\mathrm{mg} \mathrm{mL}^{-1}\right)=(0.0116 * \text { OD } 485)+0.0712
$$

\subsection{Total Lipids Extraction and Quantification}

A filter with a known amount of biomass was suspended in $100 \mu \mathrm{L}$ of ultra-pure water and $2 \mathrm{~mL}$ of concentrated $\mathrm{H}_{2} \mathrm{SO}_{4}$, then heated at $100{ }^{\circ} \mathrm{C}$ for $10 \mathrm{~min}$. A total of $5 \mathrm{~mL}$ of the freshly prepared Sulfo-Phospho-Vanillin (SPV) was added and incubated at $37^{\circ} \mathrm{C}$ at $200 \mathrm{rpm}$ for $15 \mathrm{~min}$ before it was finally read at a wavelength of $530 \mathrm{~nm}$ [35]. To determine the concentration, a calibration curve was established in the range of 0 to $1.5 \mathrm{mg} \mathrm{L}^{-1}$; the analyses were performed in triplicate. The total lipids present in the sample were determined following Equation (3):

$$
\text { Total lipids }(\mu \mathrm{g})=(\mathrm{OD} 530-0.0236) / 0.0106
$$

\subsection{Total Carotenoids Extraction and Quantification}

Filters with a known amount of biomass were put in Falcon tubes. Then, $1 \mathrm{~cm}^{3}$ of glass beads $(0.5 \mathrm{~mm})$ was added to each sample with $5 \mathrm{~mL}$ of ketone as a vehicle; then they were homogenized in a vortex at $100 \mathrm{rpm}$ for $3 \mathrm{~min}$ and centrifuged at $4500 \mathrm{rpm}$ for $10 \mathrm{~min}$ 
at $4{ }^{\circ} \mathrm{C}$. Finally, the supernatant was taken and measured at a wavelength of $450 \mathrm{~nm}$ [36]. The total carotenoid concentration was obtained using Equation (4):

$$
\text { Total carotenoids }(\mathrm{mg} / \mathrm{mL})=(\mathrm{OD} 450 * \text { sample volume } * 10) / 2500
$$

\subsection{Phycobiliproteins Extraction and Quantification}

The filters with a known amount of cyanobacterium biomass were put in Falcon tubes and suspended in $10 \mathrm{~mL}$ of $0.15 \mathrm{M}$ phosphate buffer solution, $\mathrm{pH} 7.0$, with $2 \mathrm{~g}$ of glass beads. Then, the samples were vortexed at maximum speed for 3 rounds of $2 \mathrm{~min}$, letting the sample rest for $1 \mathrm{~min}$. They were stored for $24 \mathrm{~h}, 4^{\circ} \mathrm{C}$, and then centrifuged at $3400 \mathrm{rpm}$ for $15 \mathrm{~min}$. Finally, the absorbance was measured at different wavelengths $(620,652$, and $562 \mathrm{~nm}$ ). The phycocyanin concentration was calculated using Equations (5)-(7), described by [37]:

$$
\begin{gathered}
\text { C-PC }\left(\mathrm{g} \mathrm{L}^{-1}\right)=\{[\mathrm{OD} 620-(0.474 * \mathrm{OD} 652)]\} / 5.34 \\
\text { A-PC }\left(\mathrm{g} \mathrm{L}^{-1}\right)=\{[\mathrm{OD} 652-(0.208 * \mathrm{OD} 620)]\} / 5.09 \\
\mathrm{PE}\left(\mathrm{g} \mathrm{L}^{-1}\right)=\{[\mathrm{OD} 562-(2.41 * \mathrm{C}-\mathrm{PC})-(0.849 * \mathrm{APC})]\} / 9.62
\end{gathered}
$$

\section{Results and Discussion}

\subsection{Physicochemical Characterization of Tannery Effluents}

Tannery wastewater is characterized by a dark brown color, a fetid odor due to the presence of volatile organic compounds, organic and inorganic carbon, phosphorus $(\mathrm{P})$, nitrogenous compounds (N) [38-40], fats, and other compounds. These are highly polluting in terms of COD, BOD, and total dissolved solids (TDS). According to Table 2, the effluent has a high concentration of pollutant organic matter, BOD, COD, fats and oils, and total

\begin{tabular}{|c|c|c|c|}
\hline Parameter & Units & Mean Value & $\begin{array}{c}\text { Permissible Values } \\
\text { RSL } 631 \text { (2015) of Colombia }\end{array}$ \\
\hline Nitrates & $\mathrm{mg} \mathrm{L}^{-1} \mathrm{NO}_{3}$ & $1641.00 \pm 4.34$ & Analysis and report \\
\hline Nitrites & $\mathrm{mg} \mathrm{L}^{-1} \mathrm{NO}_{2}$ & $0.15 \pm 0.0035$ & Analysis and report \\
\hline Ammonia & $\mathrm{mg} \mathrm{L}^{-1} \mathrm{~N}-\mathrm{NH}_{3}$ & $180.00 \pm 2.4$ & Analysis and report \\
\hline Total Nitrogen & $\mathrm{mg} \mathrm{L}^{-1}$ & $495.36 \pm 5.28$ & Analysis and report \\
\hline Turbidity & FAU & $1120.00 \pm 7.45$ & Analysis and report \\
\hline Phosphate & $\mathrm{mg} \mathrm{L}^{-1} \mathrm{P}_{-} \mathrm{PO}_{4}$ & $31.05 \pm 0.67$ & Analysis and report \\
\hline Total Phosphorus & $\mathrm{mg} \mathrm{L}^{-1}$ & $46.32 \pm 1.06$ & Analysis and report \\
\hline Color & $\mathrm{m}^{-1}$ & $1300.00 \pm 8.65$ & Analysis and report \\
\hline COD & $\mathrm{mg} \mathrm{L}^{-1} \mathrm{O}_{2}$ & $6720.00 \pm 5.34$ & 1200.00 \\
\hline BOD & $\mathrm{mg} \mathrm{L}^{-1} \mathrm{O}_{2}$ & $4368.00 \pm 2.34$ & 600.00 \\
\hline $\mathrm{pH}$ & $\mathrm{pH}$ units & $4.5 \pm 0.1$ & $6-9$ \\
\hline Fats and oils & $\mathrm{mg} \mathrm{L}^{-1}$ & $387.42 \pm 1.73$ & 60.00 \\
\hline $\begin{array}{l}\text { Total Suspended } \\
\text { Solids (TSS) }\end{array}$ & $\mathrm{mg} \mathrm{L}^{-1}$ & $4960.56 \pm 2.3$ & 600.00 \\
\hline $\begin{array}{l}\text { Settling Solids } \\
\text { (SSOL) }\end{array}$ & $\mathrm{mg} \mathrm{L}^{-1}$ & $315.00 \pm 1.51$ & 2.00 \\
\hline $\mathrm{Cr}$ & $\mathrm{mg} \mathrm{L}^{-1}$ & $0.17 \pm 0.002$ & 1.5 \\
\hline $\mathrm{Cd}$ & $\mathrm{mg} \mathrm{L}^{-1}$ & $0.003 \pm 0$ & 0.05 \\
\hline $\mathrm{Ni}$ & $\operatorname{mg~L}^{-1}$ & ND & $\mathrm{N} / \mathrm{A}$ \\
\hline $\mathrm{Cu}$ & $\mathrm{mg} \mathrm{L}^{-1}$ & ND & $\mathrm{N} / \mathrm{A}$ \\
\hline $\mathrm{Zn}$ & $\mathrm{mg} \mathrm{L}^{-1}$ & ND & $\mathrm{N} / \mathrm{A}$ \\
\hline $\mathrm{Fe}$ & $\mathrm{mg} \mathrm{L}^{-1}$ & 3.95 & $\mathrm{~N} / \mathrm{A}$ \\
\hline
\end{tabular}
suspended solids, which do not comply with Colombian regulations for the discharge of wastewater.

Table 2. Physicochemical characterization.

ND: not detectable; N/A: not available. 
Goswami and Mazumder [41] reported the typical characterization of tannery wastewater, in which COD concentrations of 500-11,500 $\mathrm{mg} \mathrm{L}^{-1}$ and total Kjeldahl nitrogen (TKN) of 200-550 $\mathrm{mg} \mathrm{L}^{-1}$ were observed. Regarding $\mathrm{pH}$, results of acidic $\mathrm{pH}$ between $3.4 \pm 0.0351$ and $5.96 \pm 0.0351$ [42-44] and basic pH between $8.0 \pm 0.4$ and $11.64 \pm 0.53$ have been reported [45-47]. In this work, the $\mathrm{pH}$ values were acidic, with values of $4.7 \pm 0.12$. Concerning TDS, typical values may be concentrations ranging between $2355 \pm 85 \mathrm{mg} \mathrm{L}^{-1}$ and $10,000 \pm 800 \mathrm{mg} \mathrm{L}^{-1}[48,49]$, which are very similar to the ones found in this work. For BOD, values in low ranges from $160 \pm 15.8 \mathrm{mg} \mathrm{L}^{-1}$ to $1250 \pm 38 \mathrm{mg} \mathrm{L}^{-1}$ have been reported [50], as well as values in high ranges that fluctuate between $1500 \pm 41 \mathrm{mg} \mathrm{L}^{-1}$ and $6000 \pm 30 \mathrm{mg} \mathrm{L}^{-1}$ [51]. As shown in Table 2, for this work similar results were found to those reported in the literature. Regarding the concentrations of nitrogen compounds, several authors have reported values between $129.69 \pm 7.75 \mathrm{mg} \mathrm{L}^{-1}$ and $4000 \pm 55.24 \mathrm{mg} \mathrm{L}^{-1}$ [52], which are similar to those obtained in this work $\left(1641 \mathrm{mg} \mathrm{L}^{-1}\right)$. The high concentrations of ammonia nitrogen and nitrates are possibly due to the amount of protein residues and organic matter generated by the beamhouse and tanning operations [53]. In relation to heavy metals only, the presence of $\mathrm{Cr}\left(0.17 \mathrm{mg} \mathrm{L}^{-1}\right), \mathrm{Cd}\left(0.003 \mathrm{mg} \mathrm{L}^{-1}\right)$, and Fe $\left(3.95 \mathrm{mg} \mathrm{L}^{-1}\right)$ was detected; the remaining heavy metals were not detected. Concentrations of $\mathrm{Cr}$ have been reported in tannery wastewater in the range of 2-3500 ppm $(1,48.50)$; the high contents of heavy metals, mainly $\mathrm{Cr}$ and $\mathrm{Cd}$, could be due to the excessive use of chemical compounds in the processes of the preservation of raw leather and the finishing of leather. Likewise, they could be due to the basic chromium sulfate used in the leather tanning process [54].

\subsection{Biomass Production and Nutrient Removal}

Figure 1 shows the biomass production, nitrates, phosphates, and COD and TOC removal of the treatments with the evaluated conditions that obtained the highest biomass production and pollutant removal, as well as the treatments with the lowest biomass production and pollutant removal for each strain. It can be seen in Figure 1 that the maximum biomass production values were obtained with the Chlorella sp. strain, $1.12 \mathrm{~g} \mathrm{~L}^{-1}$ (50\% TWW and $18 \mathrm{~h}$ light), followed by $1.07 \mathrm{~g} \mathrm{~L}^{-1}$ (56.2\% TWW and $13 \mathrm{~h}$ light) and $1.02 \mathrm{~g} \mathrm{~L}^{-1}(50 \% \mathrm{TWW}$ and $8 \mathrm{~h}$ light). It is noteworthy that the higher the wastewater concentration and the greater exposure to light, the higher the values obtained were. For the Scenedesmus sp. strain, the highest biomass concentration was $0.59 \mathrm{~g} \mathrm{~L}^{-1}(56.2 \%$ TWW and $13 \mathrm{~h}$ light). The phosphorus and nitrogen metabolism in wastewater is directly related to the biomass production and metabolic activities [55]. Figure 1 shows nitrate removal with values ranging from $65 \%$ to $97 \%$ for the different microorganisms used. Chlorella sp. reached the highest removal rate (97\%), while Hapalosiphon sp. obtained 94\%. The percentage of elimination of the wastewater was directly proportional-that is, the higher the concentration was, the higher the percentage of elimination was. However, for Scenedesmus sp. it was inversely proportional; the lower the concentration was, the higher the percentage of elimination was. This behavior could be described by the ionic charge of the active sites on the surface of the microalgae due to changes in the $\mathrm{pH}$ and the concentration of wastewater, which can attract or repel metals and other contaminants in solution When the concentration of wastewater increases slightly, less pollutants are absorbed, due to competition for active sites in the cell wall for pollutant assimilation [26].

Regarding the phosphorus, the removal values (Figure 1) reached percentages ranging between 15 and $73 \%$ with the use of the three microorganisms. The cyanobacterium Hapalosiphon sp. achieved the highest levels of $\mathrm{PO}_{4}$ consumption. It has been reported that phosphorus is an essential element for microalgae growth and performs many functions in cells. When it is in the form of phosphate $\left(\mathrm{PO}_{4}\right)$ the cell uses it to produce phospholipids, nucleic acids, and adenosine triphosphate (ATP); the latter os essential for all cellular processes [50], which explains the assimilation of this compound present in tannery wastewater by the strains studied. The COD removal percentages achieved in the three evaluated strains was higher than $85 \%$, and although Hapalosiphon sp. presented the highest removal levels they did not differ much from Scenedesmus sp. and Chlorella sp. The COD level is 
attributed to the growth rate and the photosynthetic activity of the microalgae strain [23]. According to the literature, effluents inoculated with microalgae had a greater reduction in COD [56], as can be seen in this work.

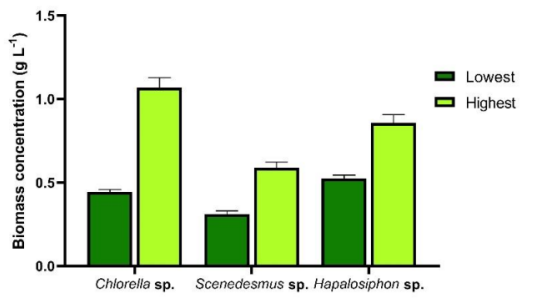

(a)

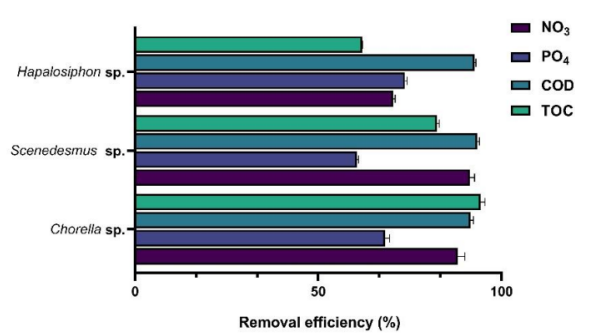

(b)

Figure 1. Biomass production (a) and removal of $\mathrm{NO}_{3}, \mathrm{PO}_{4}, \mathrm{COD}$, and TOC (b) by Chlorella sp., Scendesmus sp., and Hapalosiphon sp.

Figure 2 shows the results of the experimental design for the biomass production of Chlorella sp., Scendesmus sp., and Hapalosiphon sp. regarding the TWW concentration effect and the light/dark cycle.

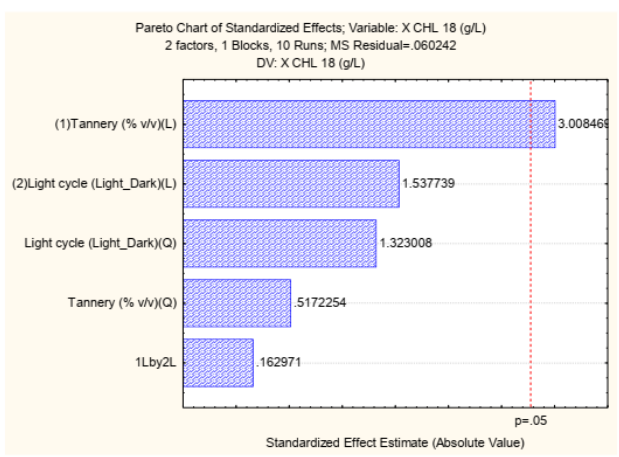

(a)

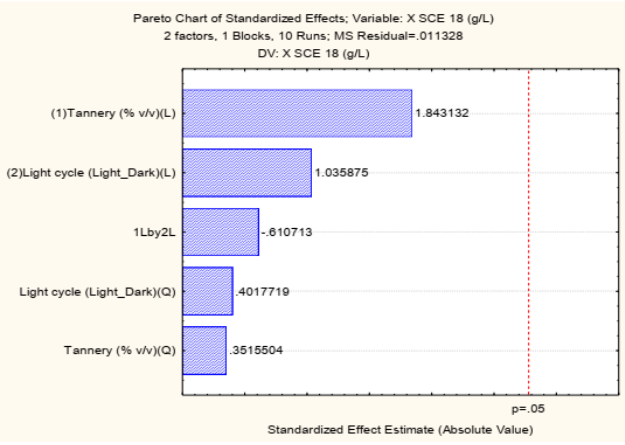

(c)



(b)

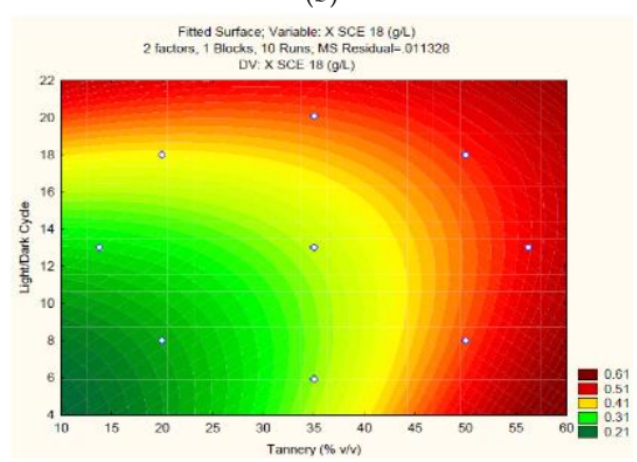

(d)

Figure 2. Cont. 


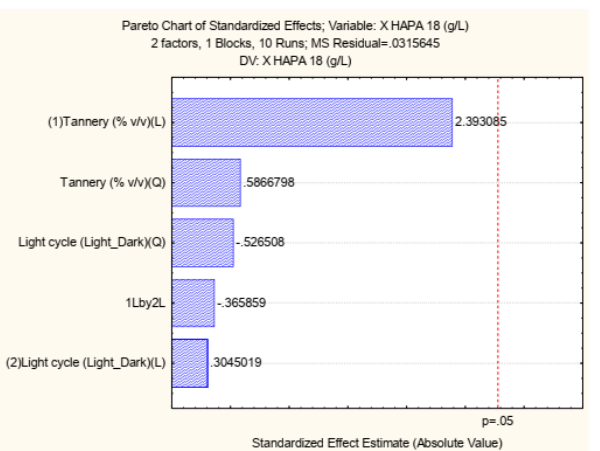

(e)

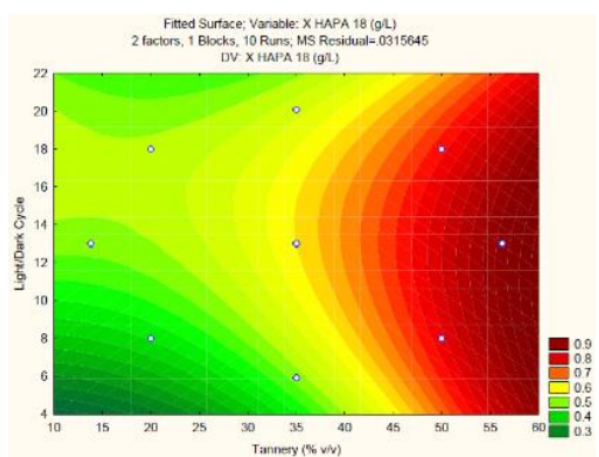

(f)

Figure 2. Pareto plot and response surface diagram in relation to biomass production and tannery wastewater. TWW concentration for Chlorella sp. (a,b) Scenedesmus sp. (c,d) Hapalosiphon sp. (e,f).

The response surface diagrams and the Pareto analysis of the experimental design (with a confidence >99.95) showed that, in the case of Chlorella sp., the dilution of the residual water affects the final biomass concentration, demonstrating that the higher the concentration of residual water $(50 \%)$ is, the higher the biomass concentrations that can be reached are. For this same strain, it is evident that although the Pareto analysis shows that the light/dark cycle has no significant difference in each treatment, the surface diagram shows that the greater the exposure to light $(20 / 4)$ is, the higher the biomass concentrations obtained are. In relation to Scenedesmus sp., it was found according to the Pareto analysis, that there are no significant differences for the concentration of residual water and light/dark cycle in the final biomass concentration, although according to the response surface diagram it is found that the higher the light/dark cycle (20/4) is, the higher the biomass concentrations that can be obtained are. Finally, for the case of Hapalosiphon sp. strain, the statistical analysis reported similar values to the Scenedesmus strain. The Pareto analysis shows that there are no significant differences for the variables evaluated, the surface diagram shows that the higher the concentration of residual water (50\%) (with a light/dark cycle between 14/10 and 18/8), the higher the biomass concentrations obtained.

De Cassia et al. [27] evaluated the influence of light intensity and the TWW concentration on biomass production and nutrient removal by Scenedesmus sp. Their results show that with a higher TWW concentration $(88.4 \%$ TWW $)$ and light intensity $(182.5 \mu \mathrm{mol}$ photons $\left.\mathrm{m}^{-2} \mathrm{~s}^{-1}\right)$, a higher biomass production was reached $\left(0.90 \mathrm{~g} \mathrm{~L}^{-1}\right)$. Thus, a direct proportional relationship for biomass production was observed. Bellén et al. [50] reported the use of Scenedesmus sp. in three different wastewater dilutions from complete leather manufacturing $(20 \%, 50 \%$, and $100 \%)$. They found that the microalgae growth was directly proportional to the effluent concentration, with the elimination of chromium $(>98 \%)$, nitrates $(>90 \%)$, phosphates $(>99 \%)$, and BOD $(>88 \%)$. In this work, similar results to those reported in the literature were found for Scenedesmus and Chlorella sp.; however, it is important to indicate that there are no reports on the application of Hapalosiphon sp. in the removal of nutrients from tannery wastewater by evaluating the wastewater concentration and the light/dark cycle. The content of other compounds present in the wastewater also influences the removal efficiency of different pollutants present in tannery wastewater, as they compete for interaction with the functional groups of the microalgae. Likewise, it was found that the interactions of $\mathrm{pH}, \mathrm{COD}$ concentration, strain used, and temperature also play an important role in biomass production using these waters $[23,56]$. Positive results have been reported [40] for Scenedesmus sp. using a central composite design, demonstrating that wastewater concentration and light intensity influence the amount of biomass produced and the removal of nitrogen and phosphorus. In this study, concentrations of wastewater of between $20 \%$ and $100 \%$ were used, and removals of $65 \%$ to $97 \%$ for nitrogen in the form of nitrate, $76.58 \%$ for phosphorus, $85 \%$ to $93 \%$ for COD, and $60.53 \%$ to $95.06 \%$ for TOC were found. 


\subsection{Culture Optimization Using Tannery Wastewater}

For biomass optimization, the results of the response surface design were used using the equations provided by Statistica 7.0 software. The equations were solved by substituting the values of photoperiod and dilution of the wastewater evaluated, obtaining the optimum photoperiod for each species, and evaluating three concentrations of tannery wastewater $(50 \%, 75 \%$ and $100 \%)$. The light/dark cycle for the strains were $24 / 0$ for Chlorella sp. and Scenedesmus sp. and 18/6 for Hapalosiphon sp. Table 3 shows the biomass production, growth rate $(\mu)$, and nutrient removal for the three TWW concentrations evaluated and the control; the control is a BOLD and BG11 medium where the organisms evaluated grow normally. The operating conditions were $1 \mathrm{vvm}$ aeration, $500 \mathrm{~mL}$ photobioreactors, with an operational volume of $300 \mathrm{~mL}, \mathrm{pH} 7 \pm 0.2$, and temperature of $28^{\circ} \mathrm{C} \pm 2{ }^{\circ} \mathrm{C}$.

Table 3. Optimal culture for biomass production and nutrient removal.

\begin{tabular}{|c|c|c|c|c|c|}
\hline \multirow{2}{*}{ Strains } & \multirow{2}{*}{ Response } & \multicolumn{4}{|c|}{$\%$ TWW } \\
\hline & & 50 & 75 & 100 & CONTROL \\
\hline \multirow{7}{*}{ Chlorella sp. } & Biomass $\left(\mathrm{g} \mathrm{L}^{-1}\right)$ & $0.9 \pm 0.1$ & $1.06 \pm 0.02$ & $1.08 \pm 0.0$ & $0.41 \pm 0.03$ \\
\hline & $\mathrm{NO}_{3}(\%)$ & $73.6 \pm 0.84$ & $78.0 \pm 1.73$ & $82.3 \pm 1.11$ & $98.6 \pm 0.16$ \\
\hline & $\mathrm{PO}_{4}(\%)$ & $53.1 \pm 1.17$ & $59.9 \pm 2.65$ & $64.8 \pm 4.27$ & $98.2 \pm 0.02$ \\
\hline & $\mu\left(d^{-1}\right)$ & $0.0876 \pm 0.0001$ & $0.0225 \pm 0.0006$ & $0.0197 \pm 0.005$ & $0.09 \pm 0.0003$ \\
\hline & $\mathrm{Cr}\left(\mathrm{mg} \mathrm{L}^{-1}\right)$ & 0.07 & 0.02 & 0 & 0 \\
\hline & $\mathrm{Cd}\left(\mathrm{mg} \mathrm{L}^{-1}\right)$ & 0 & 0 & 0 & 0 \\
\hline & $\mathrm{Fe}\left(\mathrm{mg} \mathrm{L}^{-1}\right)$ & 1.1 & 0.6 & 0.01 & 0 \\
\hline \multirow{7}{*}{ Scenedesmus sp. } & Biomass $\left(\mathrm{g} \mathrm{L}^{-1}\right)$ & $0.71 \pm 0.15$ & $0.89 \pm 0.10$ & $1.03 \pm 0.16$ & $0.30 \pm 0.12$ \\
\hline & $\mathrm{NO}_{3}(\%)$ & $84.4 \pm 0.24$ & $85.1 \pm 1.20$ & $88.1 \pm 0.27$ & $98.9 \pm 0.33$ \\
\hline & $\mathrm{PO}_{4}(\%)$ & $54.2 \pm 2.92$ & $55.5 \pm 2.75$ & $61.9 \pm 4.45$ & $98.6 \pm 0.016$ \\
\hline & $\mu\left(d^{-1}\right)$ & $0.0187 \pm 0.00034$ & $0.0236 \pm 0.0012$ & $0.0156 \pm 0$ & $0.1 \pm 0.001$ \\
\hline & $\mathrm{Cr}\left(\mathrm{mg} \mathrm{L}^{-1}\right)$ & 0.9 & 0.06 & 0.01 & 0 \\
\hline & $\mathrm{Cd}\left(\mathrm{mg} \mathrm{L}^{-1}\right)$ & 0 & 0 & 0 & 0 \\
\hline & $\mathrm{Fe}\left(\mathrm{mg} \mathrm{L}^{-1}\right)$ & 0.7 & 0.1 & 0 & 0 \\
\hline \multirow{7}{*}{ Hapalosiphon sp. } & Biomass $\left(\mathrm{g} \mathrm{L}^{-1}\right)$ & $0.65 \pm 0.76$ & $1.18 \pm 0.18$ & $1.31 \pm 0.23$ & $0.31 \pm 0.016$ \\
\hline & $\mathrm{NO}_{3}(\%)$ & $70.1 \pm 19.15$ & $87.9 \pm 1.77$ & $90.0 \pm 0.87$ & $91.1 \pm 0.19$ \\
\hline & $\mathrm{PO}_{4}(\%)$ & $49.5 \pm 1.17$ & $52.2 \pm 2.09$ & $54.1 \pm 5.60$ & $92.4 \pm 0.01$ \\
\hline & $\mu\left(d^{-1}\right)$ & $0.0436 \pm 0.0003$ & $0.0352 \pm 0.0005$ & $0.035 \pm 0.0001$ & $0.039 \pm 0.0003$ \\
\hline & $\mathrm{Cr}\left(\mathrm{mg} \mathrm{L}^{-1}\right)$ & 0.8 & 0.1 & 0.03 & 0 \\
\hline & $\mathrm{Cd}\left(\mathrm{mg} \mathrm{L}^{-1}\right)$ & 0 & 0 & 0 & 0 \\
\hline & $\mathrm{Fe}\left(\mathrm{mg} \mathrm{L}^{-1}\right)$ & 0.3 & 0.05 & 0 & 0 \\
\hline
\end{tabular}

The results in Table 3 show that the cultures with the highest TWW concentration $(100 \%$ TWW) have the highest values of biomass produced. Chlorella sp. produced $1.08 \mathrm{~g} \mathrm{~L}^{-1}$, while Scenedesmus sp. produced $1.03 \mathrm{~g} \mathrm{~L}^{-1}$. In comparison, their control reached 0.41 ad $0.30 \mathrm{~g} \mathrm{~L}^{-1}$, respectively. Finally, Hapalosiphon sp. produced $1.31 \mathrm{~g} \mathrm{~L}^{-1}$, while its control reached $0.31 \mathrm{~g} \mathrm{~L}^{-1}$. For each of the concentrations evaluated, it was found that the biomass production was higher compared to the controls. The results in relation to the growth rate show that the strain of Hapalosiphon sp. reached the highest growth rate, which was even higher than that of the control. It was possible to demonstrate how the cyanobacterium managed to grow rapidly regardless of the high coloration of the medium. In relation to the strains of Scenedesmus sp. and Chlorella sp. the growth rates were very similar and lower than those of the control. The different toxic compounds in high concentrations and the dark color of the effluent, the product of the different compounds used during the tanning process, can inhibit or minimize growth. Likewise, this prevents the entry of light into the medium and limits the growth of microalgae and cyanobacterium $[1,57]$, which explains the growth rates achieved by the strains of Chlorella sp. and Scenedesmus sp.

For nutrient consumption, the highest removals were achieved in cultures with a concentration of $100 \%$ TWW for the three strains evaluated. Regarding nitrate and phosphate, the three strains reached $\mathrm{NO}_{3}$ removal percentages of $82.3 \%, 88.1 \%$, and $90 \%$, respectively, 
and $\mathrm{PO}_{4}$ removal percentages of $64.8 \%, 61.9 \%$, and $54.1 \%$, respectively. In comparison with the controls, it was observed that the nitrogen consumption was higher, while the phosphate consumption was lower than that of the control. This may be due to the physicochemical characteristics of the wastewater, which may decrease the assimilation capacity of these compounds [51]. However, it was found that it does not significantly affect the growth of the strains evaluated in this type of effluent. Studies with Chlorella vulgaris showed significant removals of $\mathrm{COD}, \mathrm{NO}_{3}$, and $\mathrm{PO}_{4}$ of $94.74 \%, 100 \%$, and $91.73 \%$, respectively, between days 6 and 21 of culture [39]. In strains of C. vulgaris and Pseudochlorella pringsheimii, significant reductions in the concentration of pollutants were observed, higher than $65 \%$ for $\mathrm{NH}_{3}-\mathrm{N}, 100 \%$ for $\mathrm{PO}_{4}$, and $63 \%$ for COD. It should be emphasized that these results were achieved with a dilution of up to $30 \%$ of the wastewater [58]. Regarding Hapalosiphon sp., to the best of the authors' knowledge there are no reports in the literature on the cultivation of this organism in tannery waters, this being one of the first works.

\subsection{Metabolites Production}

Figure 3 shows the metabolite production percentage by Scenedesmus sp., Chlorella sp., and Hapalosiphon sp. in undiluted TWW. For the metabolite production and extraction, the three strains were cultivated with 100\% TWW. It was found that Chlorella sp. produced the highest percentages of protein (35.38\%), carbohydrates (42.94\%), and carotenoids (0.35\%). On the other hand, Hapalosiphon sp. produced the highest lipid percentages $(23.33 \%)$ and an interesting concentration of phycobiliproteins such as A-PC (4.6\%), C-PC (3.81\%), and PE $(2.51 \%)$. The protein content in microalgae varies from $20 \%$ to $70 \%$ depending on the species and the culture parameters and exhibits an amino acid profile that is suitable for human nutrition. In addition, these substances are currently being extensively researched in relation to their techno functional potential to stabilize fluid interfaces as well as their potential to satisfy the global demand for proteins. Furthermore, they can be functional ingredients such as bioactives or bio-based dyes, thus providing added value to the microalgae biorefinery [53]. Fertilizers based on microalgae and cyanobacterium have been studied to incorporate sustainability both in the recovery of soils and in the reduction in the amount of chemical fertilizers used [55]. In this work, it was found that the evaluated strains can grow using the TWW as a culture medium and generate metabolites with potential use as biofertilizers. The carbohydrate percentages obtained from each strain were greater than $25 \%$, allowing the potential use of the biomass as a carbon source for microbial cultures to obtain biofuels [56]. Saranya and Shanthakumar [28] obtained a biomass concentration of $3.51 \mathrm{~g} \mathrm{~L}^{-1}$ using tannery wastewater (30\% concentration) for C. vulgaris, but the highest amount of lipids produced (9.3\%) was obtained from a $20 \%$ concentration. In this work, the microalgae Chlorella sp. with TWW without dilution-that is, at $100 \%$-obtained a lipid percentage of $21.04 \%$, thus evidencing a higher production compared to the work previously mentioned.

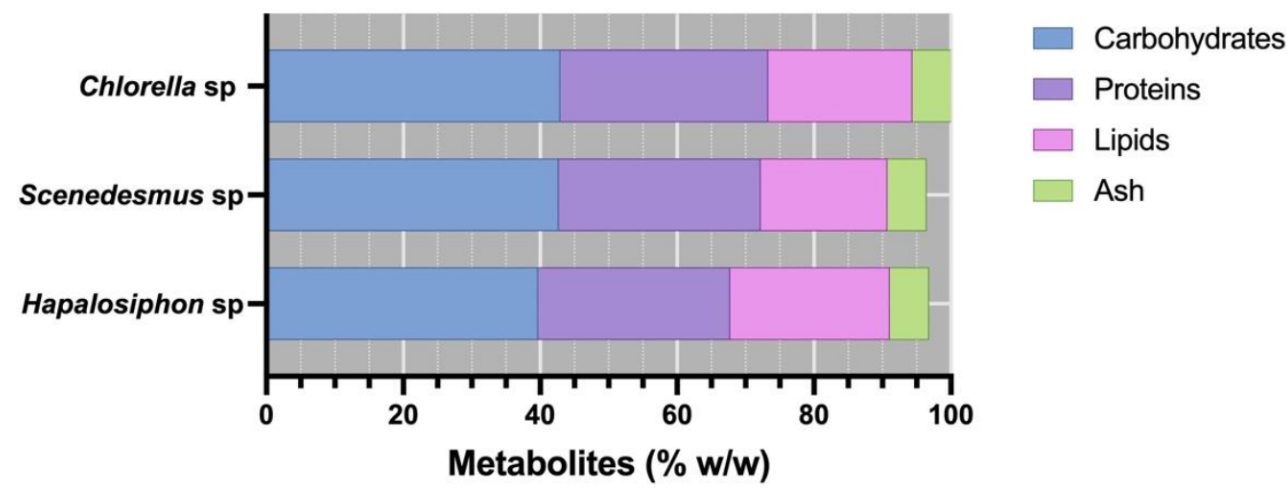

Figure 3. Metabolites produced by Scenedesmus sp., Chlorella sp., and Hapalosiphon sp.

The metabolite production rates between microalgae and cyanobacterium differ mainly due to the metabolic characteristics of these organisms. The central carbon metabolism of 
microalgae and the biochemical composition differ between microalgae such as Chlorella or Scenedesmus and cyanobacterium such as Hapalosiphon, since microalgae are eukaryotic organisms and cyanobacterium are prokaryotic [57]. The physicochemical characteristics of wastewater affect the growth of these organisms, and the presence of emerging contaminants can affect the growth and the accumulation. It has been reported that the thermodynamics of adsorption are determined by the physicochemical characteristics of the surrounding conditions, such as $\mathrm{pH}$, temperature, and redox potential [58]. If there are a wide range of contaminants present in the wastewater, this can lead to the saturation of the binding sites with contaminants, generating the inhibition or slight accumulation of metabolites [59]. Likewise, aspects such as irradiation affect metabolite production. During irradiation periods, photosynthesis produces carbohydrates that are consumed in respiration during dark periods. In general, irradiation periods are crucial for carbohydrate localization and content; the effects are different between microalgae and cyanobacterium strains. Therefore, carbohydrate accumulation can occur with particular irradiation regimes for each strain or species of microalgae and cyanobacterium [60]. The results obtained demonstrate the capacity of the organisms evaluated to reduce most of the highly environmentally polluting compounds present in the tannery wastewater used in this work, allowing the use of these effluents for the cultivation of microalgae and cyanobacterium and obtaining metabolites with potential use as biofertilizers. The low concentration of heavy metals in the wastewater and the productivities obtained allow us to continue advancing our studies for the optimization and use of the biomass generated. The use of microalgal biomass generated from the bioremediation process of tannery effluents to obtain lipids with potential use as biofuels has been reported, [61]. The success of the commercial application of these biofuels is associated with the biorefining of other metabolites such as pigments or renewable polymers that can also be used [62]. Some authors have described the behavior of microalgae in the biosorption of heavy metals; the ionic charge of the active sites of the membranes of these organisms is an important aspect of this process and depends to a great extent on the $\mathrm{pH}$. At low values, the carboxyl, hydroxyl, and sulfonate groups remain free and can therefore attract metallic cations chelating the heavy metals [63]. This aspect could be a sustainable ecological strategy that could improve the productivity of the process by recovering chromium for reuse in the tanning process, promoting sustainable economic development by obtaining a metal-free biomass that would allow diversifying its use in substances other than biofuels. [64].

\section{Conclusions}

This work demonstrates that Chlorella, Scenedesmus, and Hapalosiphon sp. can efficiently grow in wastewater from tanning processes. When the wastewater concentrations percentages were higher and the light/dark cycles more intense, high removal percentages of inorganic nutrients such as $\mathrm{NO}_{3}$ and $\mathrm{PO}_{4}$ were obtained. The removal values were higher than $90 \%$ for the three strains studied. Due to the higher wastewater concentration, there were more nutrients available in the medium and the microorganisms could thrive and grow, thus obtaining a higher biomass production. It can be seen in the experiments with a TWW concentration percentage of $100 \%$ that the microorganisms were able to metabolize the nutrients and produce value-added metabolites with a high percentage of content within the biomass. The Chlorella sp. presented the highest metabolite production values. Thus, it is concluded that the residual water from tanneries can be used as a source to produce metabolites of commercial interest.

For Chlorella and Scenedesmus sp., it can be concluded that the light/dark cycle in which they grow and assimilate the nutrients present in the tannery wastewater is $24 / 0 \mathrm{~h}$. On the other hand, this work shows that the optimal light time for Hapalosiphon sp. is between 16 and $20 \mathrm{~h}$. Regarding the wastewater concentration and microorganism growth, it is not necessary to decrease its concentration since the three strains adapted and managed to grow in undiluted water. This represents an environmental advantage by avoiding the use of water to reduce the pollutant load. 


\begin{abstract}
Author Contributions: Conceptualization, F.M.-M.; Data curation, A.F.B.-S. and N.A.U.-S.; Funding acquisition, F.M.-M.; Investigation, N.A.U.-S., D.D.A.-G., J.D.R.-A. and A.F.B.-S.; Resources, F.M.-M.; Software, N.A.U.-S. and F.M.-M.; Supervision, A.F.B.-S. and F.M.-M.; Writing-original draft preparation, N.A.U.-S., D.D.A.-G. and J.D.R.-A.; Writing-review and editing, A.F.B.-S. and F.M.-M. All authors have read and agreed to the published version of the manuscript.
\end{abstract}

Funding: This work was supported by Universidad del Valle (Colombia) with the Project "Evaluación de un sistema acoplado de oxidación avanzada en efluentes industriales y producción de microalgas para la obtención de metabolitos de alto valor agregado Grant CI 21144" and by the Newton Fund Institutional Links (ID 527624805).

\title{
Institutional Review Board Statement: Not applicable.
}

Informed Consent Statement: Not applicable.

Data Availability Statement: Not applicable.

Acknowledgments: We would like to express our sincere gratitude to Universidad del Valle and Universidad Francisco de Paula Santander for providing the equipment for this work and the Colombian Ministry of Science, Technology, and Innovation MINCIENCIAS for the support of national PhD doctorates through the Francisco José de Caldas scholarship program.

Conflicts of Interest: The authors declare no conflict of interest.

\section{References}

1. Urbina-Suarez, N.A.; Machuca-Martínez, F.; Barajas-Solano, A.F. Advanced Oxidation Processes and Biotechnological Alternatives for the Treatment of Tannery Wastewater. Molecules 2021, 26, 3222. [CrossRef]

2. Yahya, M.D.; Obayomi, K.S.; Abdulkadir, M.B.; Iyaka, Y.A.; Olugbenga, A.G. Characterization of Cobalt Ferrite-Supported Activated Carbon for Removal of Chromium and Lead Ions from Tannery Wastewater via Adsorption Equilibrium. Water Sci. Eng. 2020, 13, 202-213. [CrossRef]

3. Lofrano, G.; Belgiorno, V.; Gallo, M.; Raimo, A.; Meriç, S. Toxicity reduction in leather tanning wastewater by improved coagulation flocculation process. Glob. NEST J. 2006, 8, 151-158. [CrossRef]

4. Lv, W.; Zhao, K.; Ma, S.; Kong, L.; Dang, Z.; Chen, J.; Zhang, Y.; Hu, J. Process of Removing Heavy Metal Ions and Solids Suspended in Micro-Scale Intensified by Hydrocyclone. J. Clean. Prod. 2020, 263, 121533. [CrossRef]

5. Mayta, R.; Mayta, J. Remoción de Cromo y Demanda Química de Oxígeno de Aguas Residuales de Curtiembre Por Electrocoagulación. Rev. Soc. Química Perú 2017, 83, 331-340. Available online: http:/ /www.scielo.org.pe/scielo.php?script=sci_arttext\&pid= S1810-634X2017000300008 (accessed on 22 March 2021). [CrossRef]

6. Castellanos-Estupiñan, M.A.; Sánchez-Galvis, E.M.; García-Martínez, J.B.; Barajas-Ferreira, C.; Zuorro, A.; Barajas-Solano, A.F. Design of an Electroflotation System for the Concentration and Harvesting of Freshwater Microalgae. Chem. Eng. Trans. 2018, 64, 1-6. [CrossRef]

7. Belay, A. Impacts of Chromium from Tannery Effluent and Evaluation of Alternative Treatment Options. J. Environ. Prot. 2010, 1, 53-58. [CrossRef]

8. Najam, T.; Shah, S.S.A.; Rahman, M.M. Chapter 24-Water-Stable Metal-Organic Framework for Environmental Remediation; Saxena, G., Kumar, V., Shah, M.P.B.T.-B., Eds.; Elsevier: Amsterdam, The Netherlands, 2021; pp. 585-621. [CrossRef]

9. Cuéllar-García, D.J.; Rangel-Basto, Y.A.; Urbina-Suarez, N.A.; Barajas-Solano, A.F.; Muñoz-Peñaloza, Y.A. Lipids Production from Scenedesmus Obliquus through Carbon/Nitrogen Ratio Optimization. J. Phys. Conf. Ser. 2019, 1388, 012043. [CrossRef]

10. Sanchez-Galvis, E.M.; Cardenas-Gutierrez, I.Y.; Contreras-Ropero, J.E.; García-Martínez, J.B.; Barajas-Solano, A.F.; Zuorro, A. An Innovative Low-Cost Equipment for Electro-Concentration of Microalgal Biomass. Appl. Sci. 2020, 10, 4841. [CrossRef]

11. García, D.J.C.; Rangel-Basto, Y.A.; Barajas-Solano, A.F.; Muñoz-Peñalosa, Y.A.; Urbina-Suarez, N.A. Towards the Production of Microalgae Biofuels: The Effect of the Culture Medium on Lipid Deposition. Biotechnologia 2019, 100, 273-278. [CrossRef]

12. Barajas-Solano, A.F.; Gonzalez-Delgado, A.D.; Kafarov, V. Effect of Thermal Pre-Treatment on Fermentable Sugar Production of Chlorella Vulgaris. Chem. Eng. Trans. 2014, 37, 655-660. [CrossRef]

13. Oncel, S.S. Microalgae for a Macroenergy World. Renew. Sustain. Energy Rev. 2013, 26, 241-264. [CrossRef]

14. Chisti, Y. Biodiesel from Microalgae. Biotechnol. Adv. 2007, 25, 294-306. [CrossRef] [PubMed]

15. Lardon, L.; Hélias, A.; Sialve, B.; Steyer, J.P.; Bernard, O. Life-Cycle Assessment of Biodiesel Production from Microalgae. Environ. Sci. Technol. 2009, 43, 6475-6481. [CrossRef]

16. Benemann, J.; Woertz, I.; Lundquist, T. Life Cycle Assessment for Microalgae Oil Production. Disruptive Sci. Technol. 2012, 1, 68-78. [CrossRef]

17. de Carvalho, J.C.; Borghetti, I.A.; Cartas, L.C.; Woiciechowski, A.L.; Soccol, V.T.; Soccol, C.R. Biorefinery Integration of Microalgae Production into Cassava Processing Industry: Potential and Perspectives. Bioresour. Technol. 2018, 247, 1165-1172. [CrossRef]

18. Chen, Y.D.; Ho, S.H.; Nagarajan, D.; Ren, N.Q.; Chang, J.S. Waste Biorefineries-Integrating Anaerobic Digestion and Microalgae Cultivation for Bioenergy Production. Curr. Opin. Biotechnol. 2018, 50, 101-110. [CrossRef] 
19. Guiza Franco, L.; Orozco Rojas, L.G.; Sánchez Galvis, E.M.; García Martínez, J.B.; Barajas Ferreira, C.; Zuorro, A.; Barajas Solano, A.F. Production of Chlorella Vulgaris Biomass on UV-Treated Wastewater as an Alternative for Environmental Sustainability on High-Mountain Fisheries. Chem. Eng. Trans. 2018, 64, 517-522. [CrossRef]

20. Quintero-Dallos, V.; García-Martínez, J.B.; Contreras-Ropero, J.E.; Barajas-Solano, A.F.; Barajas-Ferrerira, C.; Lavecchia, R.; Zuorro, A. Vinasse as a Sustainable Medium for the Production of Chlorella Vulgaris UTEX 1803. Water 2019, 11, 1526. [CrossRef]

21. Ansari, F.A.; Gupta, S.K.; Nasr, M.; Rawat, I.; Bux, F. Evaluation of Various Cell Drying and Disruption Techniques for Sustainable Metabolite Extractions from Microalgae Grown in Wastewater: A Multivariate Approach. J. Clean. Prod. 2018, 182, 634-643. [CrossRef]

22. Behera, M.; Dhali, D.; Chityala, S.; Mandal, T.; Bhattacharya, P.; Mandal, D.D. Evaluation of Performance of Planococcus Sp. TRC1 an Indigenous Bacterial Isolate Monoculture as Bioremediator for Tannery Effluent. Desalin. Water Treat. 2016, 57, 13213-13224. [CrossRef]

23. Ajayan, K.V.; Selvaraju, M.; Unnikannan, P.; Sruthi, P. Phycoremediation of Tannery Wastewater Using Microalgae Scenedesmus Species. Int. J. Phytoremediat. 2015, 17, 907-916. [CrossRef]

24. Sánchez, S.; Martínez, M.E.; Espejo, M.T.; Pacheco, R.; Espinola, F.; Hodaifa, G. Mixotrophic Culture of Chlorella Pyrenoidosa with Olive-Mill Wastewater as the Nutrient Medium. J. Appl. Phycol. 2001, 13, 443-449. [CrossRef]

25. Da Fontoura, J.T.; Rolim, G.S.; Mella, B.; Farenzena, M.; Gutterres, M. Defatted Microalgal Biomass as Biosorbent for the Removal of Acid Blue 161 Dye from Tannery Effluent. J. Environ. Chem. Eng. 2017, 5, 5076-5084. [CrossRef]

26. Ardila, L.; Godoy, R.; Montenegro, L. Sorption Capacity Measurement of Chlorella Vulgaris and Scenedesmus Acutus to Remove Chromium from Tannery Waste Water. IOP Conf. Ser. Earth Environ. Sci. 2017, 83, 012031. [CrossRef]

27. Pena, A.D.D.C.; Bertoldi, C.F.; da Fontoura, J.T.; Trierweiler, L.F.; Gutterres, M. Consortium of Microalgae for Tannery Effluent Treatment. Braz. Arch. Biol. Technol. 2019, 62, 1-10. [CrossRef]

28. Nagabalaji, V.; Sivasankari, G.; Srinivasan, S.V.; Suthanthararajan, R.; Ravindranath, E. Nutrient Removal from Synthetic and Secondary Treated Sewage and Tannery Wastewater through Phycoremediation. Environ. Technol. 2019, 40, 784-792. [CrossRef]

29. Zainith, S.; Saxena, G.; Kishor, R.; Bharagava, R.N. Application of Microalgae in Industrial Effluent Treatment, Contaminants Removal, and Biodiesel Production: Opportunities, Challenges, and Future Prospects. In Bioremediation for Environmental Sustainability: Toxicity, Mechanisms of Contaminants Degradation, Detoxification, and Challenges; Elsevier: Amsterdam, The Netherlands, 2020; pp. 481-517. [CrossRef]

30. Pena, A.C.C.; Agustini, C.B.; Trierweiler, L.F.; Gutterres, M. Influence of Period Light on Cultivation of Microalgae Consortium for the Treatment of Tannery Wastewaters from Leather Finishing Stage. J. Clean. Prod. 2020, 263, 121618. [CrossRef]

31. Baird, R.; Bridgewater, L. Standard Methods for the Examination of Water and Wastewater, 23rd ed.; American Public Health Association: Washington, DC, USA, 2017.

32. Kurniawati, P.; Gusrianti, R.; Dwisiwi, B.B.; Purbaningtias, T.E.; Wiyantoko, B. Verification of Spectrophotometric Method for Nitrate Analysis in Water Samples. AIP Conf. Proc. 2017, 1911, 020012. [CrossRef]

33. Moheimani, N.R.; Webb, J.P.; Borowitzka, M.A. Bioremediation and Other Potential Applications of Coccolithophorid Algae: A Review. Algal Res. 2012, 1, 120-133. [CrossRef]

34. Slocombe, S.P.; Ross, M.; Thomas, N.; McNeill, S.; Stanley, M.S. A Rapid and General Method for Measurement of Protein in Micro-Algal Biomass. Bioresour. Technol. 2013, 129, 51-57. [CrossRef] [PubMed]

35. Frings, C.S.; Dunn, R.T. A Colorimetric Method for Determination of Total Serum Lipids Based on the Sulfo-Phospho-Vanillin Reaction. Am. J. Clin. Pathol. 1970, 53, 89-91. [CrossRef]

36. Přibyl, P.; Cepák, V.; Kaštánek, P.; Zachleder, V. Elevated Production of Carotenoids by a New Isolate of Scenedesmus Sp. Algal Res. 2015, 11, 22-27. [CrossRef]

37. Bennett, A.; Bogobad, L. Complementary Chromatic Adaptation in a Filamentous Blue-Green Alga. J. Cell Biol. 1973, 58, 419-435. [CrossRef]

38. Berkes, F. Evolution of Co-Management: Role of Knowledge Generation, Bridging Organizations and Social Learning. J. Environ. Manag. 2009, 90, 1692-1702. [CrossRef]

39. Genawi, N.M.; Ibrahim, M.H.; El-Naas, M.H.; Alshaik, A.E. Chromium Removal from Tannery Wastewater by Electrocoagulation: Optimization and Sludge Characterization. Water 2020, 12, 1374. [CrossRef]

40. Das, C.; Naseera, K.; Ram, A.; Meena, R.M.; Ramaiah, N. Bioremediation of Tannery Wastewater by a Salt-Tolerant Strain of Chlorella Vulgaris. J. Appl. Phycol. 2017, 29, 235-243. [CrossRef]

41. Goswami, S.; Mazumder, D. Treatment of Chrome Tannery Wastewater by Biological Process-A Mini Review. World Acad. Sci. Eng. Technol. Int. J. Environ. Ecol. Eng. 2013, 7, 798-804. [CrossRef]

42. Meenachi, S.; Kandasamy, S. Investigation of Tannery Liming Waste Water Using Green Synthesised Iron Oxide Nano Particles. Int. J. Environ. Anal. Chem. 2019, 99, 1286-1297. [CrossRef]

43. Ullah, R.; Ahmad, W.; Ahmad, I.; Khan, M.; Khattak, M.I.; Hussain, F. Adsorption and Recovery of Hexavalent Chromium from Tannery Wastewater over Magnetic Max Phase Composite. Sep. Sci. Technol. 2021, 56, 439-452. [CrossRef]

44. Le Luu, T. Tannery Wastewater Treatment after Activated Sludge Pre-Treatment Using Electro-Oxidation on Inactive Anodes. Clean Technol. Environ. Policy 2020, 22, 1701-1713. [CrossRef]

45. Pal, M.; Malhotra, M.; Mandal, M.K.; Paine, T.K.; Pal, P. Recycling of Wastewater from Tannery Industry through MembraneIntegrated Hybrid Treatment Using a Novel Graphene Oxide Nanocomposite. J. Water Process Eng. 2020, 36, 101324. [CrossRef] 
46. Zhou, L.; Zhang, W.; De Costa, Y.G.; Zhuang, W.Q.; Yi, S. Assessing Inorganic Components of Cake Layer in A/O Membrane Bioreactor for Physical-Chemical Treated Tannery Effluent. Chemosphere 2020, 250, 126220. [CrossRef] [PubMed]

47. Saeed, T.; Afrin, R.; Muyeed, A.A.; Sun, G. Treatment of Tannery Wastewater in a Pilot-Scale Hybrid Constructed Wetland System in Bangladesh. Chemosphere 2012, 88, 1065-1073. [CrossRef]

48. Huang, W.; Shao, H.; Zhou, S.; Zhou, Q.; Li, W.; Xing, W. Modulation of Cadmium-Induced Phytotoxicity in Cabomba Caroliniana by Urea Involves Photosynthetic Metabolism and Antioxidant Status. Ecotoxicol. Environ. Saf. 2017, 144, 88-96. [CrossRef]

49. Selvan, S.T.; Velramar, B.; Ramamurthy, D.; Balasundaram, S.; Sivamani, K. Pilot Scale Wastewater Treatment, $\mathrm{CO}_{2}$ Sequestration and Lipid Production Using Microalga, Neochloris Aquatica RDS02. Int. J. Phytoremediat. 2020, 22, 1462-1479. [CrossRef]

50. Bellén, M.; Hernández, L.; Parra, D.; Vega, A.; Pérez, K. Using Scenedesmus Sp. for the Phycoremediation of Tannery Wastezater. Tecciencia 2016, 12, 69-75. [CrossRef]

51. Kozik, V.; Barbusinski, K.; Thomas, M.; Sroda, A.; Jampilek, J.; Sochanik, A.; Smolinski, A.; Bak, A. Taguchi Method and Response Surface Methodology in the Treatment of Highly Contaminated Tannery Wastewater Using Commercial Potassium Ferrate. Materials 2019, 12, 3784. [CrossRef] [PubMed]

52. Alemu, T.; Mekonnen, A.; Leta, S. Integrated Tannery Wastewater Treatment for Effluent Reuse for Irrigation: Encouraging Water Efficiency and Sustainable Development in Developing Countries. J. Water Process Eng. 2019, 30, 100514. [CrossRef]

53. Yadav, A.; Raj, A.; Purchase, D.; Ferreira, L.F.R.; Saratale, G.D.; Bharagava, R.N. Phytotoxicity, Cytotoxicity and Genotoxicity Evaluation of Organic and Inorganic Pollutants Rich Tannery Wastewater from a Common Effluent Treatment Plant (CETP) in Unnao District, India Using Vigna Radiata and Allium Cepa. Chemosphere 2019, 224, 324-332. [CrossRef] [PubMed]

54. Bharagava, R.N.; Saxena, G.; Mulla, S.I.; Patel, D.K. Characterization and Identification of Recalcitrant Organic Pollutants (ROPs) in Tannery Wastewater and Its Phytotoxicity Evaluation for Environmental Safety. Arch. Environ. Contam. Toxicol. 2018, 75, 259-272. [CrossRef]

55. Dunn, K.; Maart, B.; Rose, P. Arthrospira (Spirulina) in Tannery Wastewaters. Part 2: Evaluation of Tannery Wastewater as Production Media for the Mass Culture of Arthrospira Biomass. Water SA 2013, 39, 279-284. [CrossRef]

56. Saranya, D.; Shanthakumar, S. Effect of Culture Conditions on Biomass Yield of Acclimatized Microalgae in Ozone Pre-Treated Tannery Effluent: A Simultaneous Exploration of Bioremediation and Lipid Accumulation Potential. J. Environ. Manag. 2020, 273, 111129. [CrossRef] [PubMed]

57. Reyes-Serrano, A.; López-Alejo, J.E.; Hernández-Cortázar, M.A.; Elizalde, I. Removing Contaminants from Tannery Wastewater by Chemical Precipitation Using $\mathrm{CaO}$ and $\mathrm{Ca}(\mathrm{OH})_{2}$. Chin. J. Chem. Eng. 2020, 28, 1107-1111. [CrossRef]

58. González-Fernández, C.; Ballesteros, M. Linking Microalgae and Cyanobacteria Culture Conditions and Key-Enzymes for Carbohydrate Accumulation. Biotechnol. Adv. 2012, 30, 1655-1661. [CrossRef]

59. Sutherland, D.L.; Ralph, P.J. Microalgal Bioremediation of Emerging Contaminants_-Opportunities and Challenges. Water Res. 2019, 164, 114921. [CrossRef]

60. Choi, S.; Song, C.W.; Shin, J.H.; Lee, S.Y. Biorefineries for the Production of Top Building Block Chemicals and Their Derivatives. Metab. Eng. 2015, 28, 223-239. [CrossRef]

61. Salama, E.S.; Kurade, M.B.; Abou-Shanab, R.A.I.; El-Dalatony, M.M.; Yang, I.S.; Min, B.; Jeon, B.H. Recent progress in microalgal biomass production coupled with wastewater treatment for biofuel generation. Renew. Sustain. Energy Rev. 2017, 79, 1189-1211. [CrossRef]

62. Sforza, E.; Kumkum, P.; Barbera, E.; Kumar, S. Bioremediation of industrial effluents: How a biochar pretreatment may increase the microalgal growth in tannery wastewater. J. Water Process Eng. 2020, 37, 101431. [CrossRef]

63. Cho, H.D.; Kim, E.Y.; Hung, Y.-T. Heavy metal removal by microbial bio sorbents. In Handbook of Environmental Engineering: Environmental Bioingenieering; Humana Press: Totowa, NJ, USA, 2010; pp. 375-402.

64. Gendy, T.S.; El-Temtamy, S.A. Commercialization potential aspects of microalgae for biofuel production: An overview. Egypt. J. Pet. 2013, 22, 43-51. [CrossRef] 